\title{
Kent Mekânının Politik Bir Meta Olarak Keşfi. Gösteriler ve Karşı-gösteriler
}

\author{
Deniz Zengin Çelik \\ Galatasaray Üniversitesi, Iletişim Fakültesi, \\ Medya ve İletişim Çalışmaları Doktora Programı, Doktora Öğrencisi \\ denizzengincelik@gmail.com
}

\section{Öz}

Tarih öncesi dönemlerden günümüze uzanan süreç boyunca kent mekânının şekillenmesindeki en önemli etkenlerden biri güç odakları olmuştur. Hem iktidar çevreleri hem de başta proletarya olmak üzere muhalif kitleler, gerçekleştirdikleri politik gösteriler ile kent mekânının şekillenmesi sürecinde başat rol üstlenmiştir. Bu bağlamda bu çalışma kentlerin gösteri kavramı etrafında nasıl şekillendiğini tarihsel bir bakış açısından ve iki farklı eksenden incelemeye çalışmaktadır: iktidarların düzenledikleri politik gösteriler ve muhalif kitlelerin gerçekleştirdikleri karşı-gösteriler. Tüm bu tarihsel süreç boyunca, kent mekânı politik çatışmaların ana hattını oluşturan bir sahne olarak karşımıza çıkmaktadır.

Anahtar kelimeler: Kent mekânı, gösteri toplumu, politik gösteriler 


\section{Discovery of Urban Space As a Political Commodity. Spectacles and}

\section{Counter-spectacles}

\section{Abstract}

From prehistoric times to the present, one of the most important factors in shaping the urban space has been the power groups. Both the ruling groups and the opposing masses, especially the proletariat, played a leading role in the process of shaping the urban space with the political spectacles they carried out. In this context, this study tries to examine how the cities are shaped around the concept of spectacle from an historical point of view and from two different axes: the political spectacles organized by the governments and the counter-spectacles of the opposing masses. Throughout this historical process, the urban space appears as a scene that forms the main line of political conflicts.

Keywords: Urban space, society of the spectacle, political spectacles

\section{La découverte de l'espace urbain comme marchandise : des spectac-} leet des contre-spectacles

\section{Résumé}

De la préhistoire à nos jours, I'un des facteurs les plus importants dans l'aménagement de l'espace urbain sont les groupes de pouvoir. Les groupes de pouvoir et les Opposants -en particulier le prolétariat-, ont joué un rôle critique dans le processus de développement de l'espace urbain avec les spectacles poli- tiques qu'ils ont réalisés. Dans ce contexte, cette étude tente d'examiner comment les villes sont structurées autour de la notion de spectacle d'un point de vue historique et sous deux angles différents: les politiques spectacles qui sont organisés par les gouvernements et les politiques de spectacle des Opposants. Tout au long de ce processus historique, l'espace urbain apparait comme une scène qui forme la principale ligne de conflit politique.

Mots-clés: Espace urbain, la société du spectacle, spectacles politiques
Kent mekânı altı bin yıl önce ilk șekillenmeye bașladığı andan beri değișim geçirmektedir. Bu değişimi yürüten temel mekanizma, genellikle gücü elinde tutan iktidarlardır. Gücü elinde bulunduranların, çıkarları ve bu çıkarları taşıyan ideolojiler çerçevesinde kent mekânı ve kentte yaşayan bireyler üzerinde söz sahibi oldukları söylenebilir. Guy Debord'a göre "gösteri", modern kentlerin merkezi organizasyon ilkesidir (1996, s. 1). Güç odaklarının kentsel mekânlara taşınan gösterileri, bu söz sahibi olma halinin bir tezahürü olarak da okunabilir. Bu çerçevede, bu makalede öncelikle kent ve iktidar arasındaki ilişkinin tarihsel süreç içerisinde gösterisellik etrafında nasıl şekillendiği ve bu bağlamı tamamlar nitelikte olan iktidarların düzenledikleri politik gösterilerin yapıları incelenmeye çalışılmıştır. Makalenin ikinci önemli ekseni olarak, özellikle sanayi devrimiyle birlikte çehresi oldukça değişen kentsel mekânlarda düzenlenen muhalif gösterilerin yapısı irdelenmiştir. Bu çizgide başta sanayi devriminin ürünü olan proletarya olmak üzere muhalif kitleler açısından kent mekânının nasıl kullanıldığı ve gösteri toplumu içinde kendine alan açma mücadelesi olarak karşı-gösterilerin nasıl oluştuğu anlaşılmaya çalışılmıştır.

\section{Kent ve İktidar İlişkisine Tarihsel Bir Bakış}

İnsan, biyolojik tarihi göz önüne alındığında görece geç bir tarihte -M.Ö. 6000-4000 yılları arasında- ilk kentleri olușturmuștur (Hatt ve Reiss, 2002, s. 29). Maden Çağı'nda, metal silah kullanabilen insanlar taştan yapılmış silahları olanlar karşısında üstün konuma geçmiştir. Silah teknolojisindeki bu sıçrama, taş silah kullananların demir, bakır ve tunç gibi madenlerden yapılan silahları kullananlar karșısında savunmasız konuma düșmesine sebep olmuș ve köleleștirilmelerini kolaylaştırmıştır. Toprakları silah zoruyla ele geçirenler hem o toprakları ekip biçenler üzerinde denetimlerini sürdürmek, hem de dışarıdan gelecek saldırılara karşı topraklarını koruyabilmek için bölgeye hâkim, yüksek ya da stratejik öneme sahip alanlara yerleşmişlerdir. Gücü elinde bulunduranların yüksek yerlere yerleşmesinin bir diğer sebebinin, kendilerini ilahi güçlere denk göstererek kurdukları korku düzeninin devamlıı̆ı̆ı sağlamak olduğu söylenmektedir (Begel, 1996, s. 8). Diğer bir ifadeyle, gücü elinde bulunduranlar, sahip oldukları metal silahların onlara getirdiği fiziksel üstünlüğü ilahi güç illüzyonu ile pekiştirerek kentin en yüksek ve stratejik alanını mesken tutmuş ve egemenliklerini meşrulaştırmıştır.

Bu tarihsel perspektiften bakıldığında kentlerin ortaya çıkmasında daha güçlü olan grupların güçsüzler üzerinde kurduğu tahakkümün tetikleyici olduğu görülse de kentlerin varlığını sürdürmesinde etkili olan asıl faktör kentin bir pazar yerine dönüşmesidir. İlk başlarda ordu karargâhı olarak kurulan kentlerde zamanla zanaatkârlık gelişmiştir. Bu yeni toplumsal kategori yönetici ve ruhban sınıfının ihtiyaçlarından fazlasını üretir duruma geldiğinde, kentler sözü edilen fazla ürünler ile kırsal ürünlerin değiş tokuşunun yapıldığı pazarlar haline gelmiştir. (Begel, 1996, s. 10). Bu yapı sınıfsal düzenlemeleri de beraberinde getirmiştir. Yönetenler, din adamları, askerler ve zanaatkârlar arasındaki ayrım artık daha belirgindir (Sjoberg, 2002, s. 45). Diğer bir ifadeyle, kentlerin olușumu ve sürekliliği toplumsal ve kültürel yapıdaki değișimleri beraberinde getirmiş, özellikle sınıfsal farkların belirginleşmesine önayak olmuştur. 
Orta Çağ'a gelindiğinde kentler yapısal, kültürel ve toplumsal açıdan değişmeye devam etmiştir. Batı Roma Imparatorluğu'nun çöküşünün ve tarımsal üretim temelli bir sosyoekonomik düzen olarak feodalizmin kurulmasının bu değișimin temel itici gücü olduğu görülmektedir. Feodal dönemde, yeni kent devletleri kurulmadığı gibi mevcut kentler ve kent uygarlığı da yıkılıp, yok edilmiştir (Begel, 1996, s. 11). Kentlerin yok edilmesi ve yeni kentlerin kurulmamasına bağlı olarak bu dönemde yașam alanlarının geniș kırlara yayıldığı görülmektedir. Bu değişim, toplumsal sınıfların ayrımını netleştirmiştir. Keleş'in aktardığına göre, bu dönemde varlıklı ve seçkin bireylerin başlı başına bir siyasal güce sahip olmayan kent merkezlerinde, yoksul veya azınlıkların ise kent çeperinde yaşadıkları bir yapı mevcuttur (2005, s. 9).

Kentlerin yeniden şekillenmesi ve iktidar-kent ilişkisinin güçlenmesi bağlamında Rönesans ve Barok dönemlerine bakmak yerinde olacaktır. Rönesans döneminde kentsel mekânın estetik ve işlevsel açıdan şekillendirilmesine özel önem verilmiş, İtalya başta olmak üzere tüm Avrupa coğrafyasında eski kentler restore edilerek yeni ve büyük meydanlar, uzun caddeler ve simetrik yapılar inşa edilmiştir (Ellis, 2011, para. 24).

Benzer şekilde 1600 'lü yıllardan sanayi devrimine kadar olan dönemde, kent mekânı bir gösteri alanı olarak șekillenmeye Barok mimari etkisi altında devam etmiştir. Bu zaman diliminde monarşiler, özellikle yeni ve gösterişli saraylar, bahçeler ve bürokrasinin hâkim olduğu devlet binaları inşa etmiştir (Ellis, 2011, para. 25). Bu dönemde kent mekânı monarşinin gücünün temsili olarak, normalden büyük devasa denilebilecek yapılarla kuşatılmış, uzun caddeler, anıtsal meydanlar ve parklar inşa edilmiştir. Bu mimari anlayışın izleri sanayi devrimi sonrasına dek uzanmaktadır. 1800'lerin sonlarına doğru çalışmaları ile dönemin Paris'ini yeniden șekillendiren Haussmann'ın kentsel düzenlemelerinin asıl amacının özellikle halkın daha iyi koşullarda yaşamasına elverişli bir Paris yaratmak olduğu ileri sürülmektedir (Eroyan, 2013, para. 5). Ancak, kentin özellikle III. Napolyon'un kent mekânı üzerindeki hâkimiyetinin ve askeri gücünün bir göstergesi olarak devasa yapıları ve onları birbirine bağlayan geniş caddeleri barındıracak şekilde düzenlendiği de gözden kaçmamalıdır. Haussman'ın çalışmaları Paris'in sınıf çatışmaları boyunca içine sürüklendiği kaotik ortamdan işçi sınıfını ve kent yoksullarını merkezden sürerek kurtulabileceğine dair ideolojik bir bakış açısının dışa vurumu olarak da okunmalıdır (Bektaş, 2017, para. 3). Bu dönemde, 550 bin Parisli kent merkezindeki inşaatlar sebebiyle merkezden uzak yerleșim alanlarına tașınmak zorunda kalmıștır (Pinder, 2000, s.366). Pinder'in aktardığına göre, Fransız şair Charles Baudelaire 1859'da kaleme aldığı şiirinde Haussman'ın Paris'i bir şantiyeye çevirdiği 20 yıllık zaman dilimine gönderme yaparak, kentin geçirdiği değișimden hüzünle bahsetmektedir (Pinder, 2000, s.359). Çünkü Paris'in geçirdiği değişim, beraberinde kente yabancılaşmayı da getirmiş, insanların gündelik yaşamlarında bir araya geldikleri park ve bahçelerin yok oluşu veya her gün yürüdükleri yolların artık yürünemez hale gelişi toplumsal ilişkileri de olumsuz yönde etkilemiştir.
Figür 1: 1860'lı yıllar Paris'inde Haussmann'ın emri ile yıkılan yapıları gösteren illüstrasyon. www.theguardian.com

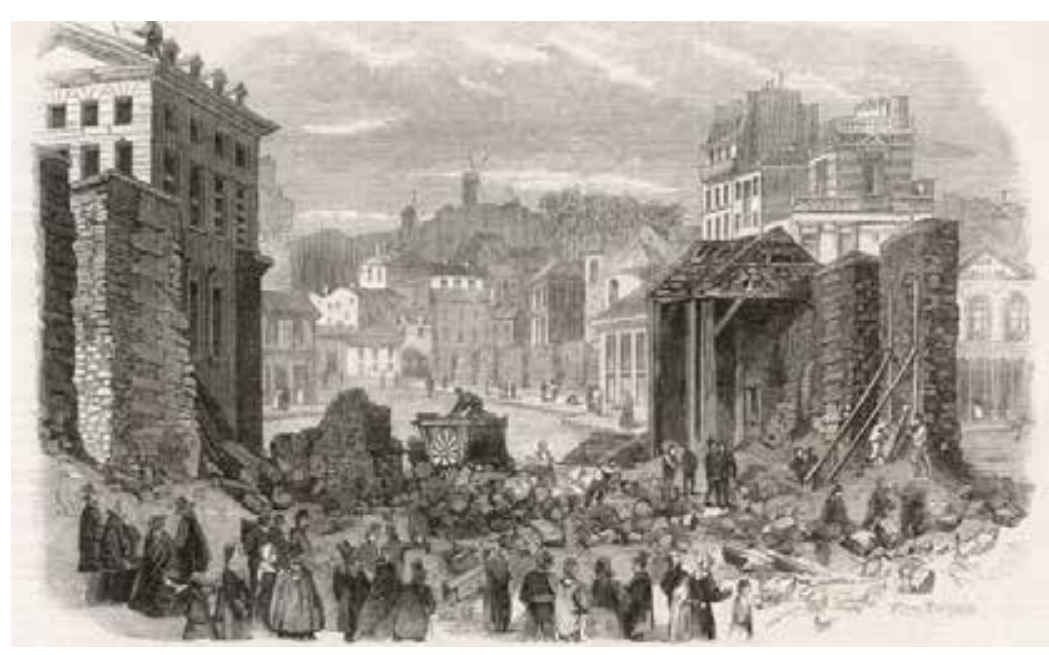

Kentlerin çehresi sanayi devrimi ile birlikte çok daha köklü değişimler geçirmiştir. Burjuvazinin politik arenadaki gücünün artışı kent dokusunun sosyo-kültürel açıdan sıkılaşmasına neden olmuş, kentler burjuva kültürünün kodlarına göre yeniden şekillenmeye başlamıştır. Bankalar, özel işletmeler, küçük fabrikalar ve ofislerin varlığı hızla artmış, buna eklenen toplu taşıma olanakları ile iletişim ve teknolojik gelişmelerin etkisiyle nüfusta hızlı bir artış yaşanmıştır (Lampard, 1955, s. 106). Özellikle işçi sınıfı-kelimenin gerçek anlamıyla- kentte barınamaz hale gelmiș, bu süreç gettoların oluşumunu hızlandırmıștır. Sanayi devriminin üretim araçlarının dönüşmesi ve el değiştirmesi üzerindeki etkisi, toplumsal, kültürel ve kentsel yapıdaki değişiklikleri de beraberinde getirmiştir. Bu dönemde kapitalizm ivme kazanmıș, Fransız Devrimi'nin de etkisiyle burjuva demokrasisi olgunlașmaya başlamıştır. Günümüzdeki formuna sanayi devrimi ile kavuşan kentler, kırsal nüfusu kitleler halinde kendisine çeken birer endüstri merkezine dönüşmüştür (Tekin, 2012, s. 77).

Görülmektedir ki, güç odakları tarihin tüm dönemlerinde kent mekânını kendi çıkarları doğrultusunda şekillendirmektedir. Günümüzde de kent mekânı özellikle sanayi devriminden bu yana hız kazanan kapitalizmin ve burjuvazinin çıkarları çerçevesinde yeniden yaratılmaktadır. Kapitalizm, üretim ve tüketim ilişkilerini metalaştırmanın yanında, mekânı da bir meta olarak yeniden üretebileceğini keşfetmiş ve mekân üzerindeki tahakkümünü artırmıştır (Lefebvre, 1976, s. 21).

Değişimi genel hatlarıyla özetlenen kent mekânı, günümüzde de kapitalizm ve burjuva kültürü etrafında şekillenmektedir. Debord'a göre, kentlerin tarihi devletin ve egemen güçlerin kent mekânı üzerindeki tahakkümünün ve hem kırı hem de kenti denetleyen mekanizmaların oluşmasının tarihidir (1996, s. 132). Bu bağ- 
lamda hem tarihsel süreç içerisinde hem de kapitalizmin de ivme kazanmasıyla ulaşılan günümüzde gösteriselliğin, hem gücü elinde tutanlar hem de muhalifler tarafından nasıl kullanıldığına, kent mekânının bu çatışmaya nasıl "sahne" olduğuna ve bu durumun nasıl bir manzara oluşturduğuna bakmak yerinde olacaktır.

\section{Otoriter Rejimlerde Gösteri}

Gösteri, kimlik ve mekân üzerine çalışan araştırmacılar, bir coğrafi bölgedeki doğal ve kültürel çevreyi manzara (landscape) olarak tanımlar. Bu kavram aynı zamanda, kentler gibi insanoğlunun kendi ihtiyaçları doğrultusunda şekillendirdiği toprak parçalarındaki insan ilişkilerini açıklamak için de kullanıı (Antrop, 2000, s. 1). Bir başka deyişle, manzara kavramı belirli bir alandaki insan ve mekân ilişkilerinin doğurduğu genel görüntüyü ifade etmektedir. Manzara kavramının mekân ile ilișkisi üzerine çalıșan araștırmacıların vurguladığı üzere, manzaralar okunacak birer metne benzetilebilir (Johnson, 2003, s. 9). Ancak son zamanlarda araştırmacılar, manzaralar ve metin arasında kurulan bu analojinin, manzara kavramını pasifleştirdiğini ve insan-mekân etkileşiminin dinamizmini yansıtmadığını belirtmektedir (Hagen ve Ostergren, 2006, s. 158). Bu sebeple, manzaraları okunacak birer metin olarak görmek yerine birer tiyatro sahnesi olarak tarif etmenin mümkün olduğunu belirtirler (Johnson, 2003, s. 10). Bir sahneye benzetilen manzarada, mekân ve insan arasındaki ilișkinin dinamizmi daha görünürdür ve mekân da en az insan kadar önemli bir gösteri unsurudur (Hagen ve Ostergren, 2006, s. 158). Hatta, bu benzetmede mekân sadece üzerinde gerçekleşen gösteriye ev sahipliği yapmaz, gösteri için bir bağlam oluşturmaktan çok daha öteye giderek, gösterinin tam da kendisine dönüşür (Johnson, 2003, s. 10).

Bu bağlamda politik gösterilerin düzenlendiği mekanlar sadece iktidarların politik gösterilerinin birer sahnesi olmakla kalmaz, kendileri başlı başına bir gösteriye, bir performansa dönüşür. Diğer yandan, mimari, müzik, sanat gibi gösteri unsurları ve ideolojinin bir arada sunulduğu bu politik gösteriler, mekân ve insan ilişkisinin yoğunlaşarak vücut bulduğu bir alan ve zaman dilimi olarak karşımıza çıkar. Böylelikle, bir güç patlaması biçiminde gösteriye başvuran otoriter rejimler düşünüldüğünde; gösteri unsurlarının kullanımı ile hem gösteriselliğin nasıl yaratılığı hem de mekânın kendisinin nasıl gösteriye dönüştüğü meselesi gündeme gelir.

Otoriter rejimlerin politik gösterilere verdiği önemin belki de ilk örneklerinden biri İngiltere'de VIII. Henry'nin tahtta olduğu 1536 yılında görülür. Bu dönem özellikle, VIII. Henry reformlarıyla Katolik Kilisesi'nin kökünden kazınarak devlet işlerinden kovulduğu bir dönemdir (Taylor, 2013, s. 102). Ingiltere'nin yönetim biçimini derinden etkileyen bu siyasi kararın çeşitli propaganda araçlarıyla desteklenmesi gerektiğini düsünen VIII. Henry matbaayı etkin bir propaganda araCı olarak kullanmıştır. Kralın sağ kolu olan Thomas Cromwell, alınan kararların meşrulaştırılması sürecinde özellikle kitleler için materyal üretilmesi gerektiğini savunmuştur. Cromwell'in başyazarlarından olan Richard Morison ise, A Persuasion to the King that the laws of the realm should be in Latin adlı eserinde, çok daha yoğun bir propaganda aracı olarak gösterilerin devreye girmesini önermiștir Yıllık ritüeller şeklinde yapılması önerilen bu gösterilerde, yakılan meydan ateşleri, şölenler, ziyafetler, tören alayları aracılığıyla halka verilmek istenen mesaj çok net bir sekilde verilebilecektir: Kralın halkı ve İngiltere'yi Roma'nın boyunduruğundan kurtarması her yıl düzenli olarak kutlanacak; bu sayede halk her gösteride Henry'ye olan bağlılı̆ını bir kez daha yeniden ve derinden hissedecek, duydukları hayranlıkla krallarının gücüne güç katacaklardır. Taylor, Morison'un kitlelere verilecek mesajın kulaklardan ziyade gözler aracılığıyla nasıl daha hızlı aktarıldığına vurgu yaptığına işaret etmektedir (2013, s. 106). Bu durum Morison'un, tören alayları, ziyafetler, şenlik ateşi gibi gösteri bileşenlerini temel propaganda aracı olarak gördüğünü göstermektedir. Bir bașka deyișle iktidarın icraatlarını genis halk kitlelerine ulaştırmanın en etkili aracı olarak gösteriler ön plana çıkarılmaktadır.

Tarihte bilinen en otoriter liderlerden olan Adolf Hitler'in Nazi Almanya'sı da bu türden sayısız propaganda gösterisine sahne olmuştur. Bunlardan en çarpıcı olanı Nasyonal Sosyalist Parti'nin Nürnberg'de 1923 ve 1938 yılları arasında düzenlediği Reich Parti Kongreleri'dir. Nürnberg, Nazi Almanya'sı için Orta Çağ Avrupa'sının ve Roma-Germen İmparatorluğu'nun önemli bir kenti olması sebebiyle sembolik bir öneme sahiptir. Burada düzenlenen gösteriler, hem kent çekirdeğinin gösterilerle uyumlu ideolojik bir perspektifle -Nazi birliğini, gücünü ve fanatizmini teatral ve abartılı bir gösteri biçimine çevirme süreci- yeniden düzenlenmesi, hem de insanları belirli bir ideoloji çerçevesinde bir araya getirmeyi amaçlayan yeni kongre alanlarının inşası üzerinden incelenebilir.

Figür 2: Nürnberg'in 1493 yllına ait bir çizimi. www. skyscrapercity. com

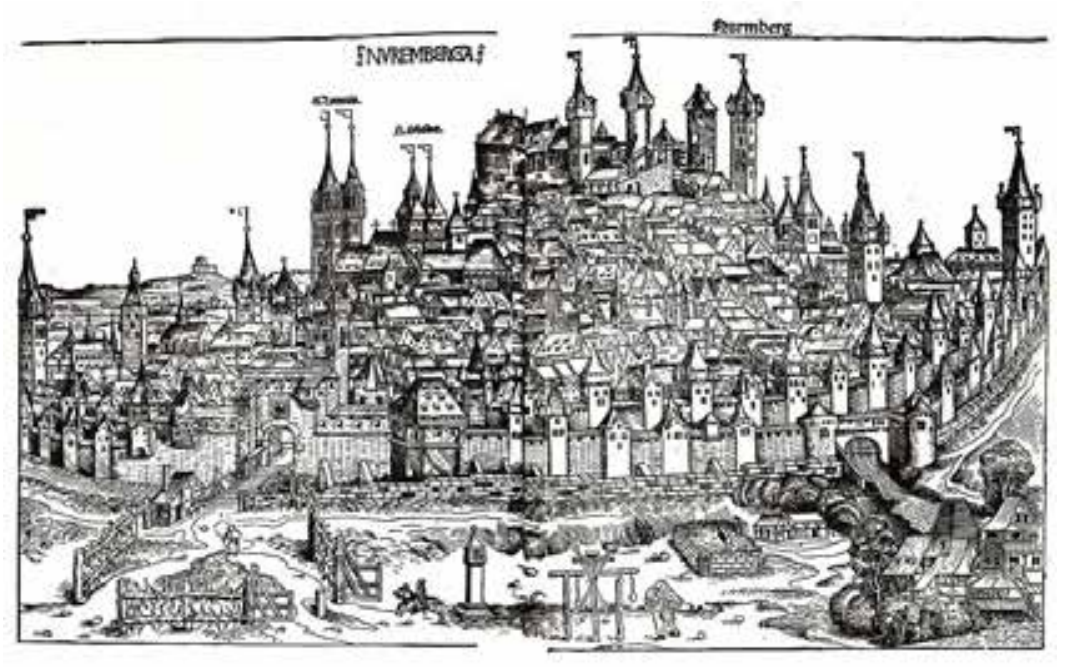


Reich Kongreleri yıllık ritüeller şeklinde gerçekleşen, binlerce insanın, askerin ve parti yetkilisinin bir araya geldiği, sekiz gün kadar süren ve Nazi rejiminin halk desteğini alma çabasıyla gerçekleştirdiği politik gösteriler olarak karşımıza çıkar (Hagen ve Ostergren, 2006, s. 159). Parti kongreleri bu temel hedefler çerçevesinde hem mimarinin, hem çeşitli gösteri unsurlarının hem de mekânın dönüşümünün nasıl ustaca bir araya getirildiğinin bir örneğidir. Bu dönemde, gösterilerin ana mekânı olacak ve Nürnberg'in "dünyanın en büyük șantiyesi" olarak nitelenmesine vesile olan devasa nitelikte yapıların inşasına başlanmıştır (Hagen ve Ostergren, 2006, s. 160). Hitler'in özel olarak ilgilendiği ve büyük önem verdiği bu kongreler için, gösteriselliğin tüm bileşenleri ustaca kullanılarak, gösteriye katılan her bireyin kendisini özel hissetmesi ve "büyülenmesi" sağlanmıș: bu amaçla mimarinin, ışık ve ses gösterilerinin, bayrak, flama ve afişlerin kullanı$\mathrm{m}$ incelikle hesaplanarak gösteriye dâhil edilmiştir. Gösteri bileşenlerini incelikle kullanan Nazi iktidarı, bir yandan büyük politik gösterileri düzenlediği kongre alanlarının inşası ile diğer yandan da kent mekânını yeniden şekillendirerek otoriter rejimlerin düzenledikleri gösterilerin en iyi örneklerden birini ortaya koymuştur. Benjamin'e atıfla söyleyecek olursak "konstrüksiyon, bilinç altının rolünü üstlenmiştir." (2001, s. 88). Bu çerçevede, kent çekirdeğinde yapılan değişikliklerin Nazi otoritesini ve meşruiyetini pekiştirmeyi amaçladığı açıktır.

Bu bağlamda günümüz Türkiye'sinden Yenikapı Miting Alanı iyi bir örnek olarak karşımıza çıkmaktadır. Yenikapı Miting alanı özellikle Türkiye'nin politik arenadaki iç çalkantılarının yoğun olduğu 2016 yılında düzenlenen "Demokrasi ve Şehitler Mitingi" ile gündeme gelmiștir. Bu miting, 2002'den beri iktidarda olan Adalet ve Kalkınma Partisi tarafından düzenlenen en gösterişli politik gösterilerden birisi olarak okunabilir. Yenikapı gösteri ve miting alanının konumu hem kent çekirdeği ile ilişkiselliği, hem de sahne olduğu ideolojik bağlamlar açısından da önemlidir.

Miting alanının inşa edildiği yer, İstanbul'un tarihi yarımadasının güney kesiminde, Theodosius Limanı olarak bilinen 8000 yıllık bir tarihe ev sahipliği yapan bir bölgedir ("istanbul Tarihçe", t.y.). İstanbul'un kurucusu olarak nitelenen Konstantin'in, İstanbul'u büyük bir kent olarak planlamasıyla beraber Yenikapı bölgesinin de önemi artmış ve o dönemde kente giriş yapan göçmenlerin ilk uğrak noktası Theodosius Limanı olmuştur (Asal, 2010, s. 22). Bu bölge, aynı zamanda Samatya ve Kumkapı semtlerine komşu olması açısından da önemlidir. Samatya Antik dönemde mezarlık olarak kullanılan, daha sonrasında balıkçılıkların yoğun olarak yaşadığı, Bizans ve Osmanlı'da ise özellikle Ermenilerin ikamet ettiği bir semt olmuştur (Koptaş, 2013, para. 12).

Bu bölgenin Ermeniler başta olmak üzere, azınlıklar ve Bizans için kültürel, dini, toplumsal önemi vardır. Bu kültürel ve tarihsel kodları yıkmak istercesine, Yenikapı miting alanı kentte yaşayanların algılarında iktidarın gösteri mekânı olarak kodlanarak tarihsel bağlamından koparımış ve mekâna yeni bir bağlam kazandırılmıştır. Bu bağlam, bölgenin geçirdiği kentsel dönüșümlerin sebep olduğu bir çehre değişimi sürecini de barındırmakta ve hem o bölgenin kendine has kentsel dokusunun değiștirilmesine hem de inșa edilen yeni gösteri alanı ile yeni bir kimliğin oluşmasına ön ayak olmaktadır.

Özetlenecek olursa, Yenikapı miting alanı iktidarın söylemlerini yeniden ürettiği ve propaganda aracı olarak kullandığı yeni bir gösteri alanı olarak kurgulanmıştır. Burada planlanan mitingler veya politik gösteriler de iktidarın bir aynası niteliğinde, bir güç temsili olarak onun söylemlerini yeniden üretme amacı taşımaktadır.

İktidarların düzenledikleri politik gösterilere verilebilecek en iyi örneklerden biri de demokratik yönetimlerde seçim dönemlerinin birer politik gösteri şeklinde organize edilmesidir. Bu gösteriler günümüz gösteri toplumlarında siyasetin de gösteriselleşme sürecine dâhil oluşunu ifade etmektedir. Türkiye özelinde bakıldığında, siyasal reklamcılığın gelişmesinin ve politik partilerin radikal söylemlerden kaçınarak merkezi politikalara yakınlık duymaya bașlamasının siyasetin gösteriselleşmesini tetikleyen temel dinamikler olduğu söylenebilir. Ayrıca, özellikle televizyon gibi kitle iletişim araçlarının yaygınlık kazanarak siyasal hayatın sergilendiği alanlara dönüşmesi de bu süreci hızlandırmıştır. Bu bağlamda, siyasi partiler tüm kesimlerin desteğini alma kaygısı ile akılda kalıcılığı yüksek imajlar üreterek siyasetin gösteriselleşmesine katkı sağlamışlardır (Akıncı ve Akın, 2013, s. 334). Akıncı ve Akın'ın da ifade ettiği gibi "İmaj yaratma üzerine kurgulanan bu yeni siyaset anlayışının pazarlama tekniklerini ve medyayı etkin kullanmasının zaman içinde siyaseti başrol oyuncusu lider olan bir gösteri sahnesine dönüştürdüğü açıktır." (2013, s. 335).

\section{Muhalif Gösterilerin Kısa Tarihi}

Tarih boyunca iktidarı elinde bulunduranlar, kent mekânını bir "sahne" gibi şekillendirmiştir. Ancak, bu sahneler aynı zamanda ezilen sınıfların ve muhaliflerin iktidara karşı kendilerini gösterdikleri, kendilerini kuşatan ve sömüren üretim ve tüketim ilişkilerine karşı tepkilerini ortaya koydukları alanlardır. Muhalif kitleler ve kent mekânı arasındaki ilişkiyi ve bu kitlelerin gerçekleştirdikleri karşı gösterilerin yapısını anlamak adına İngiltere'de sanayi devrimi sonrasındaki işçi sınıfının burjuvazi ve sanayi kapitalizmine karşı ilk muhalif tepkilerine ve bu tepkilerin nasıl evirildiğine bakmak yerinde olacaktır.

Sanayi devrimi sonrasında kapitalizmin toplumsal, kültürel ve ekonomik yapı üzerindeki etkileri derinleşmiş ve özellikle işçi sınıfı üzerindeki tahakkümü artmıştır. O dönemde kadın, erkek ve çocuk işçiler fabrikalarda ağır koşullar altında çalışmakta, günün 20 saatini fabrikalarda geçirmekteydi. Bu koşullar alında gerçekleştirilen ilk muhalif gösteriler, makinelerin üretimde kullanılmasının da yaygınlaşmasıyla makine kırma eylemleri olarak tarihe geçmiştir. Ludizm olarak da adlandıılan bu eylem biçiminde, işçiler ve mülksüzleştirilen halk çalıştıkları fabrikalara, makinelere, yollara, köprülere zarar vererek gelişen kapitalizme karşı tepkilerini ortaya koymuşlardır. Politik açıdan bakıldığında bunlar ilkel ve şiddet içeren eylemler olarak görülebilir. Ancak bunlar savaşılan düşmanın, makinelerin 
ya da fabrikaların fiziksel varlığından ziyade üretim araçlarının sahipleri olduğu bilincinin yerleşmesine de önayak olmuştur. Ayrıca bu protestolar, politik arenada dile getirilemeyen, henüz olgunlaşmamış taleplerin bir ifade şekli olarak da değerlendirilebilir (Çakır, 2005, para. 6). O nedenle, bu hareket işçi sınıfının burjuvazi ve sanayi kapitalizmine karşı ilk muhalif tepkileri olarak görülebilir. Daha sonra, -18. yüzyılın sonlarından itibaren- hızla büyüyen işçi sınıfı birleşerek sendikalar kurmaya, kapitalizmin ezici gücü karşısında kendisini ifade etme yollarını keșfetmeye başlamıştır. Sendikalar, ilk politik ve örgütlü gösterilerin yolunun açılması sürecinde önemli bir adımdır.

İşçi hareketlerinin kent ve gösteri kavramları ile nasıl ilişkilendiğini anlamak adına Marx ve Engels'in düşüncelerine bakılabilir. Marx ve Engels için kent mekânı, kapitalizmin üretim ilişkilerine karşı devrimci bir dik duruşu somutlaştırması adına önemlidir (Şengül, 2001, s. 9; Tekin, 2012, s. 77). Sengül'e göre, Engels için kent ilk politik gösterilerin oluşma potansiyelini bünyesinde barındırmaktadır (2001, s. 11).

Kent mekânı Engels'in öngördüğü üzere, tarih boyunca pek çok kez kapitalizmin gösteriselliğine karşı ezilen sınıfların ve muhaliflerin yaşam alanlarını savundukları birer sahneye dönüşmüştür. Bu sahne çoğu zaman bir kent meydanı olmaktadır. Kent meydanları, vatandaşların gündelik hayatlarını yaşamalarını engelleyen, onları kuşatan üretim ve tüketim ilişkilerine ve siyasi iktidarlara karşı varlıklarını ve güçlerini gösterebilecekleri en kullanışlı mecralar olarak karşımıza çıkmaktadır. Ayrıca, aynı kent meydanları siyasi iktidarların ve gücü elinde bulunduranların da kitleleri etkilemek, meşruiyetlerini ilan etmek ya da güçlerini sergilemek için kullandıkları alanlardır. Bunlara, Paris'teki Concorde, İstanbul'daki Taksim, Mısır'daki Tahrir ve Pekin'deki Tiananmen meydanları örnek verilebilir. Kentlerin ana arterlerinin birleşme noktası ve kentin en büyük sahneleri konumundaki meydanlar kapitalizmin otoriter ya da burjuva demokratik rejimlerine karşı toplumsal birlikteliğin icra edildiği, insanların kendi yaşam alanlarını ve haklarını savunmak için tercih ettikleri ve kalabalıklar halinde kendilerini gösterdikleri kamusal alanlardır.

Her ne kadar Marx ve Engels için kent devrimci bir nitelik taşısa da Marksist düşünür ve kuramcı Henri Lefebvre bu perspektife yeni unsurlar ekler. Lefebvre, kapitalizmin kentteki üretim ve tüketim ilișkilerini metalaștırmasının yanı sıra kenti de bir meta olarak yeniden ürettiğini belirtmektedir (1976, s. 21), ve mekânı somut ve soyut mekân şeklinde sınıflandırmaktadır. Bu sınıflandırmada somut mekân gündelik hayatın sürdügü, ihtiyaçların karşılandığı yeri işaret ederken; soyut mekân ise mekânın kullanım değerinin gerileyerek daha çok bir rant aracına dönüşmesi sürecini tanımlamaktadır. Lefebvre, bu bağlamda soyut mekân üzerinden, kapitalist sistemin mekânı bir meta haline getirerek yeniden ürettiğini belirtir (2014, Bölüm 4)

Lefebvre, devletin ve iktidarın mekân üzerindeki egemenliğinin, bir diğer ifadeyle kentin bir meta olarak keşfinin kapitalizmin devamlılığı için taşıdığı öneme değinmektedir. Ona göre mekân devlet ve iktidarlar tarafından üzerinde tahakküm kurulacak bir alandır. Devlet bu amaç doğrultusunda polis, asker gibi güvenlik güçleri ve diğer kurumlarıyla stratejik önemi olan noktalara yerleşerek kent mekânında toplumsal düzeni sağlar ve böylece iktidarı güvence altına alır (Gottdiener ve Hutchison, 2010, s. 81).

Bu noktada, Lefebvre'nin gündelik hayatın yaşandığı somut mekân kavramından ve mekânın metalaştırılmasına dair analizlerinden etkilenen Guy Debord'un, gösteri toplumu kavramına ve karşı-gösterilerin devrimsel yöntemlerine dair düşüncelerine bakmak yerinde olacaktır (Gotham ve Krier, 2008, s. 168).

Debord'a göre, günümüz gösteri toplumunda kapitalizm kent mekanını, yani doğal ve beşeri çevreyi ele geçirmekte ve bu çevreyi kendi dekoru gibi şekillendirmektedir (1996, s. 129). İktidarı elinde bulunduranlar mekânı görsel olarak illüzyonlarla dolu, gösteri formlarının ve zamanlarının yaratıldığı bir projeksiyona çevirerek kitlelerin algılarını sosyal olandan uzaklaştırırlar (Woodworth, 2015, s. 415). Imajlarla donatılan modern kentlerde insan kendine, emeğine, çevresine ve arzularına yabancılaşmıștır (Pinder, 2000, s. 361). Debord'a göre, günümüz kapitalizminde egemen güçlerin sokağa hâkim olma çabasının bir uzantısı olarak düzeni sağlamada kullandıkları araçlar artmış ve artık sokak yok olmaya başlamıştır. Ona göre, kapitalizm ve egemen güçler bir yandan iş̧̧ilerin yaşam alanlarını yok etmekte diğer yandan onların üretim ve tüketim sistemi içerisinde kalmalarını sağlayacak düzenlemeleri yapmaya devam etmektedir (1996, s. 130). Bir başka ifadeyle, iktidar tüm toplumsal alanları işgal ederek herhangi bir formda ve herhangi bir ilişki tarzında karşımıza çıkabilmektedir.

Debord'a göre "Proleter devrimi, beşerî coğrafyanın eleştirisidir." (1996, s. 133). Ona göre, gösteri toplumuna dönüșen dünyada yaşayan ve iktidar karșısında gündelik hayatın koruyucusu konumundaki halk kitleleri sadece emeğini dönüștürecek yer ve olaylara sahip olmakla yetinmemelidir (1996, s. 134). Gösteri toplumu koşullarının olgunlaştırdığı bu yabancılaşmadan kurtulmak için, bütün çevre yeniden oluşturulmalı ve mevcut koşullar tamamen değiştirilmelidir (Debord, 1996, s. 134)

Debord ve bağlı bulunduğu Durumcu Enternasyonal üyeleri, mevcut koşulların tamamen değiştirilmesinin kamusal alanlarda gerçekleştirilen teatral etkinliklerle, gösterinin kullandığı metinsel ve görsel tekniklerin tersine çevrilmesi ile olacağını düşünüyorlardı (Woodworth, 2015; Pinder, 2000; Puchner, 2004). Bu bağlamda, gündelik hayatın yeniden inşasına ön ayak olma niteliği taşıyan mimari düzenin yeniden olușturulması ve kentsel hayatın yeniden düzenlenmesi gerekmektedir. Ertaş'ın (2011, s. 37) aktardığına göre, Durumcu Enternasyonal için gündelik hayat bir başlangıç noktası olarak alınıp mevcut üretim ve tüketim ilișkileri alaşağı edilmeden bireylerin kendi yașamlarını ve çevrelerini sarmalayan toplumu fark etmeleri imkansızdır. Doğaldır ki, mevcut üretim ve tüketim mekanizmalarının alaşağı edilmesi sınıfsı bir toplumu gerektirir. Bu haliyle, Durumcu Enternasyonal esneklik ve değiștirilebilirlik temelinde bir mimari düzen öngörmektedir. Kent mekânının bir iktidar eliyle şekillendirilmesi yerine, halkın kendi 
mekânlarını kendisinin tasarladığı ve șekillendirebildiği bir kent tahayyül edilir. Bu kentte, "kendi kendini üreten kent sahnesi kitlelerin yeni 'durumlar' inşa etmesine zemin oluşturur. Bir başka ifadeyle, kent mekânı onun kullanıcısı ve aynı zamanda yaratıcısı olanlara yeni deneyimler sunar." (2011, s. 37).

Kent mekânı, gösteri ve iktidar ilişkileri üzerine çalışan çağdaş bilim insanları Debord'un tanımladığı gösteri ve gösteri toplumu kavramlarında çelişkilerin olduğunu ileri sürmektedir (Woodworth, 2015; Pinder, 2000; Swyngedouw, 2002; Gotham, 2005, 2011; Gotham ve Krier, 2008; Angelini, 2015). Woodworth'e göre, gösteri toplumu koșullarında gerçekleşen direniş gösterileri süreçlerini anlamak, onu güçlü olanın eliyle dikte edilen bir yapı olarak görmek yerine, gösterinin çoğulcu ve dinamik yapısını ortaya çıkarmaya yardım edecektir. Bir başka ifadeyle Woodworth gösteri mekanizmalarının tek yönlü bir tahakküm ilişkisi olarak okunmasına alternatif olarak gösterinin içinde mücadeleyi de barındırdığı, radikal direniş olasılıklarına zemin hazırladığı, devrimsel eyleme bir kapı araladığı görüşünü öne sürmektedir.

Her ne kadar gösteri baskınlığını hissettirse, kent mekânını şekillendirerek ele geçirse de muhalif gösteriler iktidarın ve kapitalizmin gösterisinin taktiklerini kendi karşı gösterisini yaratmak için kullanmaktadır (Mayer, 2013, s. 12). Mercer ve Mayfield (2015, s. 511), karşı-gösteri kavramını gösteri formlarının önce kabul edilmesi, benimsenmesi sonrasında ise yıkılması ve tahrip edilmesi olarak tanımlamaktadırlar. Buna göre, karşı-gösteri kavramı ile hem muhalif kitlesel politik gösteriler hem de meydanlar ve büyük modern yapıların üzerini kaplayan grafiti gibi sanatlar, kent merkezinde ve meydanlarında gerçekleştirilen kaykay gibi sporlar, hem de "gerilla bahçeciliği" gibi kent mekânının dönüşümüne zemin hazırlayan eylemler birer karşı-gösteri olarak karşımıza çıkmaktadır.

Max Woodworth (2015), bir karşı-gösteri örneği olarak Zhang Dali'nin Pekin'deki grafiti eserlerinden biri olan "Dialoque" nin 1995-2005 yılları arasındaki gelişim sürecini ele alır. Woodworth makalesinde Çin'in bu dönemde geçirdiği kentsel dönüşümleri, mega yapıların inşasını, büyük çaplı fiziksel ve sosyal değişiklikleri yani asıında kent mekânının gösteri bağlamında geçirdiği değişiklikleri ele alır. Ona göre, Zhang Dali'nin grafiti projesi Pekin'in geçirdiği büyük kentsel dönüşüm karşısında bir karşı-gösteridir. Woodworth, bu dönemde gerçekleştirilen kitlesel (geleneksel) muhalif gösterilerin de olduğunu, ancak Zhang Dali'nin grafitilerinin özellikle yıkık dökük binalar ve dönüșümün yoğun olduğu alanlarda yer alarak muhalif bir tepkiye dönüștüğünü, sanatın da bu vesileyle bir karşı-gösteri olarak kendini konumlandırdığını dile getirmektedir (2015, s. 419).

\section{Sonuç Yerine}

Bu makalede, kent mekânı ve güç odakları arasındaki ilişkiler gösteri kavramı bağlamında tarihsel bir perspektiften değerlendirilmiştir. Iktidarların ve güç odaklarının tarihin tüm dönemlerinde hem üretim ve tüketim ilişkilerini hem de kent mekânını kendi çıkarları doğrultusunda bir meta olarak yeniden ürettikleri ve bu sayede varlıklarını ve devamlııklarını sağladıkları görülmektedir.

iktidarlar tarih boyunca mimari ve sehir planlama unsurlarını kullanarak kentleri kendi güçlerini sergiledikleri bir mecraya dönüştürürler. Bunun en iyi örneklerinden biri, 1800'lü yılların Paris'inde Haussman'ın kent çekirdeğinde yaptığı değișikliklerdir. Haussman'ın III. Napolyon'un emriyle yaptığı bu değișiklikler, Parislilerin kent merkezinden dışlanmasına, kent ile kurdukları ilişkinin bozulmasına ve onların sosyal ve kültürel ilişkilerinin zedelenmesine sebep olmuştur. Diğer yandan, yeni Paris'in büyük ve gösterişli yapıları ile kentsel düzenlemesi, devletin ve III. Napolyun'un gücünün ve otoritesinin bir göstergesi niteliğindedir.

İktidarlar, bir yandan kentleri mimari açıdan şekillendirerek diğer yandan kentlerde düzenledikleri politik gösterilerle gündelik hayat üzerindeki baskılarını artırmaktadır. İnsanın sosyal, kültürel ve toplumsal tüm aktivitelerinin gerçekleştiği kentleri bir tiyatro sahnesine benzetecek olursak, iktidarlar kent mekânında düzenledikleri gösterilerde mimari, sanat, ses ve imaj gibi gösteri bileşenlerini kullanarak o mekanları doğrudan performansın kendisine çevirirler. Diğer bir deyișle, kentsel mekân bir yandan şehircilik faaliyetleri ve kentsel planlamalar ile düzenlenirken diğer yandan üzerinde gerçekleştirilen politik gösteriler ile özellikle sanayi devriminden bu yana hız kazanan kapitalizmin çıkarları çerçevesinde bütünüyle bir gösteriye dönüșmektedir. Guy Debord mekânın gösteri toplumu çerçevesinde kapitalist tüketimin hizmetine girdiğine işaret eder ve "gösteri" yi modern kentlerin merkezi organizasyon ilkesi olarak görür (1996, s. 1). Gösteri bağlamında organize olan ve imajlarla donatılan modern kentlerde ise, artık insan kendine ve çevresine yabancılaşmıştır.

Bunun yanı sıra, muhalif gösteriler de iktidarın ve kapitalizmin gösterisinin taktiklerini kendi karşı gösterilerini yaratmak için kullanmaktan geri durmazlar. Bu bağlamda, Debord'un gösteri toplumuna dair sunduğu karamsar çerçevenin resmedildiği madalyonun tersini çevirerek, gösterinin çoğulcu ve dinamik yapısına da bakmak gerekir (Woodworth, 2015). Gösteri mekanizmalarının tek yönlü bir tahakküm ilişkisi olarak okunmasına alternatif olarak gösterilerin içinde mücadeleyi barındırdığı ve devrimsel eyleme bir kapı araladığı da mutlaka hatırlanmalıdır.

\section{Kaynakça}

Akıncı, M., \& Akın, E. (2013). Siyasetin Gösterileşmesi, Lider Olgusu ve Seçmen Tercihi. AiBÜ-ïBF Ekonomik ve Sosyal Araştırmalar Dergisi, 2(9), 329-352.

Angelini, A. (2015). Ludic maps and capitalist spectacle in Rio de Janeiro. Geoforum, 65, 421-430.

Antrop, M. (2000). Geography and landscape science. Belgeo. Revue belge de géographie, (1-2-3-4), 9-36. doi:10.4000/belgeo.13975

Asal, R. (2010). Yenikapı Marmaray ve metro kurtarma kazıları buluntuları ışı̆̆ında 
İstanbulıun Roma ve Bizans Dönemi deniz ticareti (Yüksek lisans tezi). Erişim adresi: http://dspace.trakya.edu.tr/xmlui/handle/1/1281\#sthash.pcyG6Yh8.dpbs

Begel, E. E. (1996). Kentlerin doğuşu. Cogito Kent ve Kültür. İstanbul: Yapı Kredi Yayınları

Bektaş, L. (2017). Şehirciliğin Soyut Mekânı ve Gündelik Hayatın Toplumsal Mekânı. XXI Dergisi, Erişim adresi: https://xxi.com.tr/i/sehirciligin-soyut-mekani-vs-gundelik-hayatin-toplumsal-mekani

Benjamin, W, (2001). Pasajlar, (Ahmet Cemal, Çev.). İstanbul: Yapı Kredi Yayınları Çakır, M. (2005). İşçilerin İlkel Tepki Biçimi Olarak Makine Kırıcılık. Erişim adresi: http://sendika63.org/2005/07/iscilerin-ilkel-tepki-bicimi-olarak-makine-kiricilik-s-murat-cakir-4098/

Debord, G. (1996). Gösteri toplumu (6. bs.). (Ayşen Ekmekçi ve Okşan Taşkent, Çev.). İstanbul: Ayrıntı Yayınları.

Ellis, C. (2011). History of cities and city planning. Ders Notları. Erişim adresi: http://www.art.net/ hopkins/Don/simcity/manual/history.html

Eroyan, A. (2013). Haussmann'ın Paris'i Gerçekten Haussmann'ın Eseri mi? Erişim adresi: http://www.mimarizm.com/haberler/haussmann-in-paris-i-gercekten-haussmann-in-eseri-mi_117518?PageNo=1

Ertaş, H. (2011). The situationist international on the 1960's radical architecture: an overview (Doktora tezi).

Gottdiener, M., Hutchison, R., (2010). The new urban sociology (4. bs.). Erişim adresi: https://ebookcentral.proquest.com

Gotham, K. F. (2005). Theorizing urban spectacles. City, 9(2), 225-246. doi:10.1080/13604810500197020

Gotham, K. F. ve Krier, D. A. (2008). From the culture industry to the society of the spectacle: critical theory and the Situationist International. Harry F. Dahms (Ed.), No Social Science without Critical Theory (s. 155-192) içinde. Emerald Group Publishing Limited.

Gotham, K. F. (2011). Resisting urban spectacle: The 1984 Louisiana World Exposition and the contradictions of mega events. Urban Studies, 48(1), 197-214.

Hagen, J. ve Ostergren, R. (2006). Spectacle, architecture and place at the Nuremberg Party Rallies: projecting a Nazi vision of past, present and future. Cultural geographies, 13(2), 157-181.

Hatt, P. K. ve Reiss, A. J. (2002). Kentsel Yerleşimlerin Tarihi. B. Duru ve A. Alkan (Ed. ve Çev.). 20. Yüzyıl Kenti (s. 27-36) içinde. Ankara: İmge Kitabevi.

İstanbul Tarihçe. (t.y.). T.C. Kültür ve Turizm Bakanlığı. İstanbul ì Kültür ve Turizm Müdürlüğü. Erişim adresi: http://www.istanbulkulturturizm.gov.tr/TR,165066/tarihce.html
Johnson, N. C. (2003). Ireland, the Great War and the geography of remembrance. Vol. 35. Cambridge University Press.

Keleş, R. (2005). Kent ve kültür üzerine. Mülkiye Dergisi, 29(246), 9-18.

Koptaş, R. (2013). Göç, sürgün, ölüm viz geldi... Samatya'da umut hep yeniden doğdu. Agos. Erişim adresi: http://www.agos.com.tr/tr/yazi/4118/goc-surgun-olum-viz-geldi-samatyada-umut-hep-yeniden-dogdu

Lampard, E. E. (1955). The history of cities in the economically advanced areas. Economic Development and Cultural Change, 3(2), 81-136.

Lefebvre, H. (1976). The survival of capitalism: reproduction of the relations of production. (Frank Bryant Çev.). New York: St. Martin's Press.

Lefebvre, H. (2014). Mekânın üretimi. (Işık Ergüden, Çev.). İstanbul: Sel Yayıncılık.

Mayer, M. (2013). First world urban activism: Beyond austerity urbanism and creative city politics. City, 17(1), 5-19.

Mercer, D. ve Mayfield, P. (2015). City of the Spectacle: White Night Melbourne and the politics of public space. Australian Geographer, 46(4), 507-534.

Pinder, D. (2000). "Old Paris Is No More": Geographies of Spectacle and Anti Spectacle. Antipode, 32(4), 357-386.

Sjoberg, G. (2002). Sanayi Öncesi Kenti. B. Duru ve A. Alkan (Ed. ve Çev.). 20 Yüzyıl Kenti (s. 37-54) içinde. Ankara: İmge Kitabevi.

Swyngedouw, E. (2002). The strange respectability of the situationist city in the society of the spectacle. International Journal of Urban and Regional Research, 26(1), 153-165.

Şekil 1 [Dijital fotoğraf], (2018), Erişim adresi: https://www.theguardian.com/ cities/2016/mar/31/story-cities-12-paris-baron-haussmann-france-urban-planner-napoleon

Şekil 2 [Dijital fotoğraf], (2018), Erişim adresi: http://www.skyscrapercity.com/ showthread.php?t=580109

Şengül, T. (2001). Sınıf mücadelesi ve kent mekânı. Praksis Dergisi, Bahar, (2), 9-31.

Taylor, P. M. (2013). Munitions of the mind: A history of propaganda. Oxford University Press.

Tekin, N. (2012). Tüketim Temelli Hayat Tarzları ve Gösteri Mekânı Olarak Kentler. ILETi-Ş-IM, 68-84.

Woodworth, M. D. (2015). From the shadows of the spectacular city: Zhang Dali's Dialogue and counter-spectacle in globalizing Beijing, 1995-2005. Geoforum, 65, 413-420. 
